\title{
Fungsi Hukum dalam Penataan Pulau- Pulau Kecil di Nusa Tenggara Barat
}

\author{
Lalu Wirentangun \\ Program Studi Magister Ilmu Hukum Universitas Mataram \\ Email: wirentangun@gmail.com
}

\begin{abstract}
ABSTRAK
Dalam pemanfaatnnya, banyak terjadi permsalahan yang timbul dalam pemberian hak atas tanah terhadap pulau-pulau kecil yang ada di NTB, oleh sebab itu perlu sekiranya dikaji berkenaan dengan pengelolan pulau- pulau kecil tersebut. Rumusan masalah dalam penelitian ini adalah bagaimana dasar fungsi hukum dalam penataan pulau-pulau kecil yang mencerminkan fungsi hukum integratif , mekanisme dan faktor-faktor yang mempengaruhi hukum dalam penataan pulau-pulau kecil. Metode penelitian yang digunakan adalah penilitan hukum normatif. Terdapat konflik norma yang terjadi pada aturan hukum terhadap penataan pulau-pulau kecil yakni antara Perkaban No. 17 Tahun 2016 dengan Perkaban No. 3 Tahun 1999 sehingga menimbulkan konflik norma. Sehingga ada beberapa faktor yang mempengaruhi kebijakan hukum integratif dalam penataan pulau-pulau kecil di Nusa Tenggara barat diantaranya masalah konflik norma pengaturan pulau-pulau kecil tersebut, faktor penegakan hukum, faktor sarana dan fasilitas pendukung serta faktor ekonomi. Oleh sebab itu, perlu adanya pengaturan hukum yang jelas.
\end{abstract}

Kata kunci : Kebijakan Hukum, Penataan Pulau-Pulau Kecil

\section{ABSTRACT}

In pemgunannya, many problems that arise in the granting of land rights to small islands in NTB, therefore need to be studied with regard pengelolan small islands. The formulation of the problem in this research is how the basic function of law in the arrangement of small islands that reflect integrative legal functions, mechanisms and factors that affect the law in the arrangement of small islands. The research method used is normative legal research. There is a conflict of norms that occur in the rule of law on the arrangement of small islands namely between Perkaban no. 17 of 2016 with No Census. 3 of 1999, causing conflict of norms. So there are several factors that influence integrative legal policy in the arrangement of small islands in West Nusa Tenggara, such as the conflict of norms concerning the arrangement of small islands, law enforcement factors, facilities and supporting facilities and economic factors. Therefore, there is a need for clear legal arrangements.

Keywords: legal policy, arrangement of small islands 


\section{A. PENDAHULUAN}

Untuk mengoptimalkan pengelolaan dan pemanfaatan daerah pesisir dan pulaupulau kecil yang ada di Indonesia, maka sebagaimana amanat dari Pasal 24 ayat (1) UU No. 26 Tahun 2007 tentang Penataan Ruang menjelaskan bahwa rencana rinci tata ruang sebagaimana dimaksud dalam Pasal 14 ayat (3) huruf b ditetapkan dengan peraturan daerah. Tata ruang wilayah yang dimaksud mencakup ruang darat, ruang laut, dan ruang udara, termasuk ruang didalam bumi. Sementara itu Pasal 9 ayat (5) UU No. 1 Tahun 2014 Rencana Zonasi Wilayah Pesisir dan Pulau-Pulau Kecil juga ditetapkan melalui Peraturan Daerah.

Salah satu daerah yang saat ini sedang giatny mengelola pembangunan sumber daya alam yang dimiliki melalui pengelolaan tata ruang terpadu baik terhadap wilayah pesisir maupun pulaupulau kecilnya adalah Provinsi Nusa Tenggara Barat.

Pembangunan di NTB dimaksudkan untuk memaksimalkan pemanfaatan dan pemberdayagunaan semua potensi yang dimiliki oleh daerah dengan mengacu pada RPJPD Provinsi NTB Tahun 2005-2025. Program dan visi pembangunan Provinsi NTB dalam Peraturan Daerah Nomor 1 Tahun 2009 Tentang Rencana Pembangunan Jangka Menengah Daerah (RPJMD) tahun 2010-2014 adalah terwujudnya masyarakat "NTB Bersaing" yang artinya beriman, dan berdayasaing. ${ }^{1}$

Dalam proses pengelolaan pulaupulau kecil yang ada di NTB, tentu tidak terlepas dari berbagai permasalahan terutama dari segi sengketa maupun konflik yang terjadi baik antara masyarakat penghuni pulau-pulau kecil tersebut dengan investor dan pemerintah yang

\footnotetext{
${ }^{1}$ Anonym. Perencanaan dan Pengembangan Wisata Alternatif di Gili Balu Sumbawa. www.google.com. Diakses pada tanggal 23 Januari 2017
}

hendak memanfaatkannya dari segi ekonomis.

Kecendungan bahwa wilayah pesisir dan pulau-pulau kecil mengalami kerusakan akibat adanya aktifitas yang memanfaatkan sumber dayanya secara berlebihan dan juga akibat akumulasi dari kegiatan berbagai sektor di wilayah pesisir dan pulau-pulau kecil. Kesadaran masyarakat terhadap nilai strategis dari pengelolaan wilayah pesisir dan pulaupulau kecil secara berkelanjutan, terpadu dan berbasis masyarakat relaif kurang. Keterbatasan partisipasi masyarakat dalam pengelolaan sumber daya pesisir dan pulau-pulau kecil menunjukkan bahwa prinsip pengelolaan sumber daya pesisir dan pulau-pulau kecil belum terintegrasi dengan pembangunan diberbagai sektor di daerah tersebut. ${ }^{2}$

Selain itu, yang tidak kalah pentingnya adalah timbulnya konflik pertanahan sebagai akibat saling klaim ha katas tanah oleh pihak-pihak yang berkepentingan guna memanfaatkan lahan yang ada pada pulau- pulau kecil tersebut. Banyaknya kasus sengketa yang terjadi menimbulkan opini publik bahwa pemerintah daerah cendrung melindungi kepentingan investor daripada kepentingan masyarakat itu sendiri. Memang betul jika pengembangan pariwisata yang ada di NTB khususnya yang ada di gili-gili berdampak pada terbukanya lapangan pekerjaan, namun masyarakat merasa mereka hanya menjadi buruh ditanah sendiri karna mereka tidak memiliki lahan untuk membangun tempat-tempat wisata seperti hotel dan Café yang keseluruhannya sudah hampir dikuasai oleh pihak investor.

Oleh sebab itu, perlu adanya kebijakan yang mencerminkan hukum integratif dimana diharapkan baik pemerintah maupun masyarakat saling

${ }^{2}$ Sudharto P. Hadi, Dimensi Sosial Dan Lingkungan Pengelolaan Wilayah Pesisir, Makalah Seminar Pengelolaan Wilayah Pesisir Terpadu, UNDIP, Semarang, 7 Oktober 2004. Hal. 5 
bersinergi demi menjawab tantangan pembangunan masadepan khususnya dalam upaya pengelolaan dan pengembangan pulau-pulau kecil yanga da di Nusa Tenggara Barat. ${ }^{3}$

Dari uraian latar belakang diatas, maka perlu sekiranya dirumuskan beberapa permasalahan yakni :Bagaimanakah dasar fungsi hukum dalam penataan pulau-pulau kecil yang mencerminkan fungsi hukum integrative ?, Bagaimanakah mekanisme fungsi hukum dalam persyaratan menata hak pada pulau-pulau kecil ?, Faktor-faktor apakah yang mempengaruhi hukum dalam penataan pulau-pulau kecil ?.

\section{B. METODE PENELITIAN}

Jenis penelitian ini adalah penelitian Hukum Normatif dengan beberapa pendekatan yakni Pendekatan Konseptual (Conseptual Approach) dan pendekatan Statuta atau peraturan perundangan (Statute Approach). Adapun teknik pengumpulan data dalam penelitian ini adalah dengan cara menggabungkan Data Primer dengan Data Sekunder, serta mengkaitkanya dengan kasus-kasus yang ada, guna mendapatkan data yang akurat sehingga tesis ini mendapatkan data yang akurat serta tesis ini dapat di susun secara sistematis dan logis. Data yang diperoleh melalui penelitian penelitian akan dianalisis secara kualitatif. Analisis seeara kualitatif yaitu analisis data dengan mengelompokkan dan menyelidiki data yang diperoleh dari penelitian menurut kualitas dan kebenarannya, kemudian diperoleh jawaban atas permasalahan yang diajukan. Selanjutnya penulis menggunakan metode deskriptif yaitu metode penyampaian dari hasil analisis dengan memilih data yang menggambarkan keadaan sebenarnya. Analisa dilakukan secara kualitatif, berlaku

3 Satjipto Rahardjo, Hukum Progresif: Sebuah Sintesa Hukum Indonesia, Yogyakarta: Genta Publishing, 2009, hlm. 2 bagi kasus yang diteliti dan hasil analisa tersebut bentuk tesis.

\section{PEMBAHASAN}

\section{Penataan Pulau-Pulau Kecil Yang Mencerminkan Fungsi Hukum Integratif}

Jumlah pulau Indonesia yang telah diverifikasi dan diberi nama hingga kini mencapai 13.466 pulau, yang tersebar di wilayah nusantara dengan total panjang garis pantai $95.181 \mathrm{~km} 2$ dan menjadikan Indonesia sebagai negara kepulauan terbesar di dunia. Pulau-pulau kecil yang memiliki luas kurang dari atau sama dengan

$2.000 \mathrm{~km} 2$, merupakan kesatuan ekosistem yang memiliki potensi sumberdaya alam pesisir dan laut yang produktif, seperti ekosistem mangrove, terumbu karang dan ekosistem lamun beserta biota yang hidup di dalamnya yang merupakan sumber bahan makanan, kawasan rekreasi, pariwisata, konservasi dan jenis pemanfaatan lainnya. Jika dikelola dengan baik, maka segenap potensi ekonomi yang ada di kawasan pulau-pulau kecil sangat prospektif untuk dikembangkan untuk meningkatkan kesejahteraan masyarakat dan dapat menyumbangkan pendapatan bagi daerah. ${ }^{4}$

Pulau-pulau kecil memiliki karakteristik yang berbeda dengan pulau besar. Secara fisik, pulau-pulau kecil Indonesia umumnya berukuran kecil, bahkan sebagian besar berukuran di bawah $1.000 \mathrm{~km} 2$ hingga kurang dari 1 Ha, umumnya terpisah jauh dari pulau induk sehingga bersifat insular (remote) dan tidak mampu mempengaruhi hidroklimat laut. Pulau-pulau kecil memiliki daya dukung (carrying capacity) terbatas, terutama ketersediaan air tawar karena daerah tangkapannya (catchment area) yang kecil. Pulau- pulau kecil juga

${ }^{4}$ Adrianto L. Pembangunan dan Pengelolaan Pulaupulau Kecil yang Berkelanjutan. Makalah disampaikan pada Pelatihan Perencanaan dan Pengelolaan Wilayah Pesisir secara Terpadu, Bogor, 23 Agustus 2004. Hal. 3 
memiliki kerentanan yang tinggi terhadap perubahan lingkungan dan dampak perubahan iklim dan bencana alam, seperti tsunami, badai dan gelombang ekstrim, naiknya paras muka laut, dan gempa bumi.

Namun demikian, pulau-pulau kecil cenderung memiliki jenis- jenis endemik dan keanekaragaman hayati laut yang tinggi, seperti ekosistem terumbu karang, ikan-ikan karang, ekosistem mangrove, dan lamun. Pulau-pulau kecil juga memiliki ekosistem pantai yang indah, perairan pantai yang jernih dan bersih, ombak yang bagus untuk berselancar, laguna serta panorama alam yang menakjubkan. Secara sosial-budaya, pulau-pulau kecil Indonesia sebagian besar tidak berpenduduk. Pada pulau yang berpenduduk, populasi umumnya terbatas dan bersifat homogen, sehingga masyarakatnya memiliki karakteristik yang spesifik. Beberapa masyarakat pulau-pulau kecil memiliki kekayaan budaya dan kearifan lokal yang unik, seperti atraksi budaya, ritual adat dan keagamaan. ${ }^{5}$

Secara ekonomi, pulau-pulau kecil umumnya masih terbatas dalam hal infrastruktur dasar dan aksessibilitas, seperti permukiman, kesehatan, pendidikan, listrik, dan komunikasi. Tingkat pendapatan dan kesejahteraan masyarakat juga relatif rendah. ${ }^{6}$

Kendala yang cukup berat terutama terkait dengan aksessibilitas yang rendah, biaya pembangunan yang tinggi, dan ketersediaan sumberdaya manusia yang sangat terbatas. Kondisi ini berdampak pada masih minimnya ketersediaan infrastruktur dasar, seperti fasilitas pendidikan, kesehatan, listrik, komunikasi (telepon, televisi, radio), dan air bersih, apalagi infrastruktur untuk pengembangan ekonomi penduduk. Minimnya akses terhadap pendidikan dan

\footnotetext{
Syamsu Alam, Pulau-Pulau Kecil: Analisis Pemanfaatan Ruang Dalam Pengelolaan Wilayah Pesisir dan Pulaupulau Kecil.Selayar, Sulawesi Selatan, 2008, hlm. 28

${ }^{6}$ Dewi Yanuarita, Analisa Pulau-pulau Kecil: Analisis Pengembangan Wisata Bahari Dipulau-pulau Bagian Selatan Kab. Selayar, Universitas Hasanuddin Makassar, 2003, hlm. 32
}

komunikasi membuat kualitas SDM di pulau-pulau kecil umumnya rendah, demikian pula dengan pengetahuan dan keterampilan teknis dalam mengelola sumberdaya dan mengembangkan alternatif mata pencaharian. Dampak dari kondisi tersebut adalah tingginya angka kemiskinan penduduk dan degradasi lingkungan di pulau-pulau kecil. Aktivitas IUU (illegal, unreported, and unregulated) fishing yang merusak terumbu karang dan penebangan liar mangrove masih marak terjadi di pulau-pulau kecil.

Pemanfaatan pulau-pulau kecil dan perairan di sekitarnya telah diatur dalam Undang-Undang Nomor 27 tahun 2007 pasal 23 ayat (2) dan Peraturan Menteri Kelautan dan Perikanan Nomor 20 Tahun 2008. Pemanfaatan pulau-pulau kecil dan perairan di sekitarnya diprioritaskan untuk salah satu atau lebih kepentingan berikut, yaitu: a) konservasi, b) pendidikan dan pelatihan, c) penelitian dan pengembangan, d) budidaya laut, e) pariwisata, f) usaha dan industri perikanan secara lestari, g) pertanian organik, dan $h$ ) peternakan. Salah satu potensi kelautan dan jasa lingkungan yang menonjol di pulau-pulau kecil adalah perikanan dan pariwisata, terutama pulau- pulau yang masuk kawasan konservasi.

Semakin meningkatnya pembangunan ekonomi di kawasan pulau-pulau kecil akan semakin meningkatkan pula ancaman terhadap degradasi ekosistem dan sumberdaya alam pulau-pulau kecil, seperti eksploitasi berlebih, degradasi habitat, pencemaran limbah, dan penurunan keanekaragaman hayati. Karena itu, untuk mempertahankan dan melindungi keberadaan dan kualitas ekosistem dan sumberdaya alam pesisir dan laut di kawasan pulau-pulau kecil yang menjadi tumpuan pembangunan kelautan secara berkelanjutan, diperlukan suatu pengelolaan yang terpadu berbasis ekosistem salah satunya dengan menetapkan dan mengembangkan kawasan konservasi laut pulau-pulau kecil. 
Tidak hanya pada persoalan ekosistem pada pulau-pulau kecil, permasalahan penguasaan terhadap lahan pada pulau-pulua kecil juga menjadi persoalan yang sudah lama harus diberikan solusi. Sebagaimana mana penjelasan penulis pada latar belakang, permasalahan pertanahan seperti tumpang tindih kepemilikan lahan hingga masalah kepemilikan lahan yang melebihi batas luas wilayah yang sudah ditentukan menjadi permasalahan yang perlu dikaji oleh masing-masing pemerintah daerah.

Oleh sebab itu, menurut penulis, harus adanya kebijakan hukum integratif dimana aturan-aturan yang telah berlaku harus ditegakkan dan untuk mewujudkannya, harus ada sinergi antara pihak pemerintah, investor dengan masyrakat. Untuk mewujudkan fungsi kebijakan hukum integratif dalam pengelolaan pulau-pulau kecil, khususnya pulau-pulau terluar maupun pulaupulau kecil yang memiliki potensi wisata tinggi, aspek pemahaman dan implementasi dari undang-undang Nomor 27 tahun 2007 harus difahami dari beberapa aspek yakni Perencanaan yang bersinergi dan pengelolaan yang optimal.

\section{Mekanisme Fungsi Hukum Dalam Persyaratan Menata Hak Pada Pulau-Pulau Kecil}

Untuk mewujudkan strategi penataan pulau-pulau kecil sebagaimana yang penulis telah jelaskan diatas, maka salah satu yang sangat perlu diperhatikan adalah aspek penataan hak pada pulaupulau kecil tersebut. Hal ini tentunya tidak terlepas dari strategi kebijakan pemerintah dalam menguasai sumber daya alam di Indonesia agar setiap pengelolaan, peruntukan maupun pemanfaataannya bisa dirasakan oleh masyrakat.

Penataan hak pada pulau-pulau kecil ini dimaksud agar setiap orang yang ingin memiliki alas hak katas pulau-pulau kecil tersebut dapat diakomodir dan tidak bertentangan dengan peraturan perundang- undangan sehingga tujuan dari Penataan Ruang khususnya di masing-masing daerah berjalan sesuai dengan yang telah di rencanakan.

Berdasarkan ketentuan Pasal 1 angka 13 Undang-Undang Nomor 26 Tahun 2007, menyatakan yang dimaksud dengan perencanaan tata ruang adalah suatu proses untuk menentukan struktur ruang dan pola ruang yang meliputi penyusunan dan penetapan rencana tata ruang. Perencanaan tata ruang dimaksudkan untuk menyerasikan berbagai kegiatan sektor pembangunan, sehingga dalam memanfaatkan lahan dan ruang dapat dilakukan secara optimal, efisien, dan serasi. Adapun tujuan diadakannya perencanaan tata ruang itu sendiri adalah untuk mengarahkan struktur dan lokasi beserta hubungan fungsionalnya yang serasi dan seimbang dalam rangka pemanfaatan sumber daya manusia, sehingga tercapainya hasil pembangunan yang optimal dan efisien bagi peningkatan kualitas manusia dan kualitas lingkungan hidup yang berkelanjutan.

Perencanaan tata ruang berdasarkan ketentuan Pasal 14 Undang-Undang Nomor 26 Tahun 2007 dilakukan untuk menghasilkan rencana umum tata ruang dan rencana rinci tata ruang.

Untuk melaksanakan ketentuan Penataan Ruang dalam UU No 26 tahun 2007 tersebut khususnya dalam penataan pulau-pulau kecil secara khusus diatur dalam Undang-Undang Nomor 27 Tahun 2007 tentang Pengelolaan Wilayah Pesisir dan Pulau-pulau Kecil.

Dijelaskan dalam pasal 1 angka 1 Undang-Undang Nomor 27 Tahun 2007 bahwa Pengelolaan Wilayah Pesisir dan Pulau-Pulau Kecil adalah suatu proses perencanaan, pemanfaatan, pengawasan, dan pengendalian Sumber Daya Pesisir dan Pulau-Pulau Kecil antarsektor, antara Pemerintah dan Pemerintah Daerah, 
antara ekosistem darat dan laut, serta antara ilmu pengetahuan dan manajemen untuk meningkatkan kesejahteraan masyarakat.

Sementara itu, yang dimaksud dengan pulau-pulau kecil dalam undangundang ini adalah pulau dengan luas lebih kecil atau sama dengan $2.000 \mathrm{~km}^{2}$ (dua ribu kilometer persegi) beserta kesatuan Ekosistemnya.

Terkait dengan pengaturan penataan hak pada pulau-pulau kecil, secara mendasar, setiap perolehan diatur secara khusus dalam Peraturan Mentri Agraria dan Tata Ruang/ Kepala Badan Pertanahan Nasional Nomor 17 Tahun 2016 tentang Penataan Pertanahan di Wilayah Pesisir dan Pulau-pulau Kecil. Dijelaskan dalam pasal 2 bahwa penataan wilayah pesisir dan pulau-pulau kecil adalah untuk memberikan arahan dan batasan penguasaan, pemilikan, penggunaan dan pemanfaatan tanah di wilayah pesisir dan pulau-pulau kecil.

Selanjutnya guna mengakomodir kepemilikan hak atas tanah pada pulaupulau kecil maka dijelaskan dalam pasal 9 bahwa : Pemberian hak atas tanah di pulau-pulau kecil harus memperhatikan ketentuan sebagai berikut : Penguasaan atas pulau-pulau kecil paling banyak $70 \%$ (tujuh puluh persen) dari luas pulau, atau sesuai dengan arahan rencana tata ruang wilayah provinsi/ kabupaten/ kota dan / atau rencana zonasi pulau kecil tersebut. Sisa paling sedikit 30\% (tiga puluh persen) luas pulau kecil yang ada dikuasai langsung oleh Negara dan digunakan dan dimanfaatkan untuk akwasan lindung, area publik, atau kepentingan masyarakat dan Harus mengalokasikan $30 \%$ (tiga puluh persen) dari luas pulau untuk kawasan lindung.

Dari hasil analisa penulis, persyaratan perolehan hak atas tanah pada pulau-pulau kecil sebagaimana yang diatur dalam pasal 9 PERKABAN No 17 tahun 2016 tersebut, terdapat pertentangan norma dengan yang diatur dalam Peraturan Menteri Negara Agraria/ Kepala Badan Pertanahan Nasinal Nomor 3 Tahun 1999 Tentang Pelimpahan Kewenangan Pemberian Dan Pembatalan Keputusan Pemberian Hak Atas Tanah Negara.

Didalam ketentuan pasal 3 PERKABAN No 3 Tahun 1999 dijelaskan bahwa : Kepala Kantor Pertanahan Kabupaten/Kotamadya memberi keputusan mengenai : pemberian Hak Milik atas tanah pertanian yang luasnya tidak lebih dari $2 \mathrm{Ha}$ (dua hektar), pemberian Hak Milik atas tanah non pertanian yang luasnya tidak lebih dari 2.000 M2 (dua ribu meter persegi), kecuali mengenai tanah bekas Hak Guna Usaha.

Jika meurujuk pada ketentuan pasal 3 PERKABAN No 3 tahun 1999 tersebut, maka setia orang/individu secara tunggal dapat memproleh hak atas tanah terhadap pulau kecil jika pulau tersebut kurang dari 2 Hektar, sehingga apa yang dijelaskan dalam kententuan pasal 9 PERKABAN No 17 Tahun 2016 yang mensyaratkan seorang /individu hanya boleh menguasai suatu pulau kecil tidak lebih dari $70 \%$ dapat di kesampingkan.

Hal ini tentu dapat menimbulkan konflik pertanahan yang berkepangjangan mengingat masih banyak pulau-pulau kecil yang ada di Indonesia yang luasnya tidak lebih dari 2 Hektar. Terlebih jika pulau-pulau tersebut merupakan pulaupulau kecil yang memiliki ekosistem yang cocok untuk dikembangkan sebagai daerah pariwisata sebagaiamana banyaknya pulau-pulau kecil yang ada di Nusa Tenggara Barat. Pulau-pulau kecil atau yang sering disebut dengan Gili tersebut, saat ini masih banyak ditemukan sengketa pertanahan baik berkenaan dengan tumpang tindih hak atas tanah maupun permasalahan kepemilikan pulau-pulau kecil yang dikuasai oleh seorang/ individu tanpa memperhatikan ketentuan dari PERKABAN No. 17 Tahun 2016 tersebut. 


\section{Faktor-Faktor yang Mempengaruhi Hukum dalam Penataan Pulau- Pulau Kecil di Nusa Tenggara Barat}

Dengan keindahan pantainya, perairan laut dan terumbu karang serta keanekaragaman hayati yang tinggi, provinsi NTB telah menjadi tujuan wisata pantai dan harai kedua terbesar di Indonesia setelah bali. Berdasarkan Perda No. 9/1989 telah ditetapkan 15 kawasan wisata andalan dimana 9 terdapat di Pulau Lombok dan 6 di pulau Sumbawa).

Selain itu, berdasarkan Peraturan Daerah Nomor 3 Tahun 2010 tentang Rencana Tata Ruang Wilayah Provinsi Nusa Tenggara Barat 2009-2029, telah ditetapkan 12 Kawasan Strategi Provinsi (KSP) untuk kepentingan pertumbuhan ekonomi.

Perkembangan pemanfaatan pesisir dan pulau-pulau kecil di Provinsi NTB sangatlah pesat. Hal ini ditandai dengan semakin berkembangnya sarana-prasarana pariwisata seperti hotel, restaurant hingga tempat-tempat rekreasi yang telah terbangun di wilayah pesisir dan pulau-pulau kecil sebagaimana yang telah berkembang di Gili Matra (Meno, Air, dan Trawangan), Pantai senggigi, Gili Nanggu, Pantai Kuta, Pulau Paserang, hingga ke Pulau Moyo. Wilayah pesisir dan pulau-pulau kecil di NTB disamping dikembangkan untuk keperluan ekonomi, juga digunakan sebagai kawasan lindung dan konservasi. Tercatat beberapa kawasan telah ditetapkan oleh Menteri Kehutanan seperti TWAL Pulau Moyo dan TWAL pulau satonda, ditetapkan oleh Menteri Kelautan dan Perikanan seperti TWP Gili Meno, Gili Air dan Trawangan serta 7 kawasan telah dicadangkan oleh Pemerintah Kabupaten/Kota sebagai Kawasan Konservasi Perairan Daerah.

Hal ini juga mendukung dinamika penduduk dan pembangunan di NTB dari waktu ke waktu semakin meningkat. Sejalan dengan kecendrungan tersebut, permintaan terhadap sumberdaya alam akan semakin bertambah untuk mendukung pertumbuhan yang di inginkan guna meningkatkan kesejahteraan masyarakat. Disadari bahwa tingkat bahwa tingkat pemnafaatan sumber daya alam yang terdapat didarat intensitasnya demikian tinggi, menyebabkan daya dukung hampir mencapai taraf ambang batas. Sebaliknya, sumberdaya pesisir dan pulau-pulau kecil belum dimanfaatkan secara optimal, padahal potensinya sangat besar. Dengan demikian sumberdaya pesisir dan pulau-pulau kecil merupakan harapan masa depan bagi kemajuan dan kesejahteraan penduduk NTB.

Pemanfaatan wilayah pesisir dan pulau-pulau kecil di NTB tidak hanya untukmengembangkan satu sektor saja, tetapi juga untuk berbagai sektor pembangunan lainnya termasuk perhubungan, pertambangan, industry, pertanian, kehutanan hingga konservasi.

Dalam rangkai mencapai tujuantujuan wilayah khususnya pada pulaupulau kecil secara terpadu dan berkelanjutan, perlu dirumuskan konsep pengelolaan yang mampu mengintegrasikan setiap kepentingan dalam keseimbangan antara dimensi ekologis, social, budaya maupun penerapan peraturan yang ada. penyusunan strategi pengelolaan wilayah pulau-pulau kecil yang dimanfaatkan untuk berbagai sektor pembangunan memiliki kompleksitas isu, permasalahan, peluang, dan tantangan pembangunan.

Dalam Undang-undang Nomor 27 tahun 2007 tentang Pengelolaan wilayah pesisir dan pulau-pulau kecil serta peraturan menteri kelautan dan Perikanan nomor PER.16/MEN/2018 tenteng perencanaan pengolahan wilayah pesisir dan pulau-pulau kecil, dinyatakan bahwa pengolahan wilayah pesisir dan pulaupulau adalah suatu rangkaian kegiatan perencanaan, pemanfaatan, pengawasan, dan pengendalian sumberdaya yang 
dilakukan antarsektor, antarpemerintah dan pemerintah daerah, antarekosistem darat dan laut, serta antarilmu pengetahuan dan teknologi untuk meningkatkan kesejahteraan masyarakat.

Pengelolaan wilayah pesisir dan pulau-pulau kecil dilakukan untuk melindungi (konservasi dan rehabilatasi), memanfaatkan dan memperkaya sumberdaya serta sistem ekologis secara berkelanjutan. Disamping itu, pengelolaan wilayah tersebut juga bertujuan untuk meningkatkan nilai social, ekonomi, dan budaya masyarakat melalui peransertanya dalam memanfaatkan sumberdaya alam secara lestari. Untuk mencapai tujuan tersebut, perlu disusun rencana pengolaan wilayah pesisir dan pulau-pulau kecil secara terpadu dan berkelanjutan. Undang-undang nomor 27 tahun 2007 dan peraturan menteri kelautan dan perikanan nomor PER.16/MEN/2008, mengatakan bahwa pemerintah daerah diwajibkan menyusun rencana pengelolaan wilayah pesisir dan pulau-pulau kecil (WP-3-K) yang meliputi: 1) Rencana strategis wilayah pesisir dan pulau-pulau kecil (RSWP-3-K); 2) Rencana zonasi wilayah pesisir dan pulau-pulau kecil (ZSWP-3-K); 3) Rencana pengelolaan wilayah pesisir dan pulau-pulau kecil (RPWP-3-K); dan 4) Rencana aksi pengelolaan wilayah pesisir dan pulau-pulau kecil (RAPWP-3-K);

Dalam implementasinya, dokumen rencana strategis wilayah pesisir dan pulau-pulau kecil, merupakan bagian yang tidak terpisahkan dan/atau sebagai komplemen dari penyusunan rencana pembangunan jangka panjang daerah (RPJPD) selama 20 (dua puluh) tahun, dan sekurang-kurangnya dapata ditinjau kembali 5 tahun sekali. Rencana kegiatan tersebut diharapkan dapat ditinjau sebagai pedoman pengelolaan wilayah pesisir dan pulau-pulau kecil Provinsi NTB.

Dalam proses pelaksanaan pengelolaan khususnya terhadap pulau- pulau kecil di NTB, masih banyak sekali permasalahan yang timbul akibat kurang optimalnya kinerja pemerintah dengan daya dukung lainnya. Merujuk pada dokumen Draf Awal Rencana Strategi Wilayah Pesisir dan Pulau-pulau Kecil NTB, ada beberapa hal yang menjadi permasalahan dalam pengelolaan pulaupulau kecil di NTB yakni : 1) Kualitas SDM di wilayah pulau-pulau kecil masih sangat rendah dan terbatas. 2) Kualitas dan kuantitas SDM aparatur dibidang pengelolaan WP3K masih terbatas, 3) Potensi konflik dan tumpang tindih kewenangan pengelolaan WP3K 4)

Sarana dan prasarana pendukung pengelolaan WP3K masih terbatas 5) Angka kemiskinan di WP3K masih tinggi 6) Pencemaran dan kerusakan lingkungan (terumbu karang, erosi/abrasi pantai) 7) Overfishing dan illegal fishing (penangkapan ikan tidak ramah lingkungan, jenis yang dilindungi) 8) Belum tertibnya perijinan pemanfaatan sumberdaya pesisir dan pulau-pulau kecil 9) Orientasi pembangunan belum berbasis pada sumberdaya kelautan 10) Lemahnya penerapan Iptek 11) Sistem data dan informasi WP3K masih berbasis dan belum terpadu 12) Belum optimal pemanfaatan potensi SDA dan jasa-jasa lingkungan 13) Keterbatasan akses permodalan (perbankan, kelembagaan, pasar) 14) Lemahnya koordinasi pengelolaan WP3K 15) Pengawasan dan penegakan hukum masih lemah 16) Kualitas dan diversitas produk perikanan dan kelautan masih lemah 17) Jiwa kewirausahaan masyarakat pesisir dan pulau-pulau kecil masih rendah

Selain permasalahan diatas, salah satu permasalahan yg urgen untuk di tangani oleh pemerintah adalah berkenaan dengan pemberian hak atas tanah terhadap pulau pulau kecil yang ada di NTB. Sebagaimana yang penulis jelaskan pada BAB sebelumnya, bahwa jika merujuk pada PERKABAN No. 17 Tahun 2016, maka setiap pulau termasuk 
pulau-pulau kecil hanya bisa dikuasai tidak lebih dari $70 \%$, dan sisanya $30 \%$ harus disediakan untuk konservasi alam. Salah satu tujuan dari ketentuan PEKABAN tersebut adalah agar setiap pulau tidak hanya digunakan untuk kepentingan komersial semata, namun tetap harus dijaga kelestariannya sehingga tidak di eksploitasi secara berlebihan. Tujuan lainnya adalah, agar tidak adanya penguasaan atas tanah oleh satu orang/indivisu saja, artinya tidak ada yg boleh membeli pulau untuk di kuasai dan dimanfaatkan sendiri.

Namun, jika merujuk pada ketentuan PERKABAN No. 3 tahun 1999, dijelaskan bahwa setiap orng dapat memperoleh hak atas tanah jika tanah tersebut kurang dari 2 hektar. Sementara dari hasil pengamatan penulis serta dokumen yang penulis peroleh di BPN Provinsi NTB, ada banyak pulaupulau kecil di NTB yang luasnya kurang dari 2 Hektar. (dokumen terlampir) Pulau-pulau tersebut tentunya memiliki potensi pariwisata yang sangat tinggi. Hal ini tentunya dapat memunculkan adanya monopoli penguasaan hak atas tanah terhadap pulau-pulau kecil yang luas nya kurang dari 2 hektar oleh satu pemegang hak. Sementara.

Jika kembali merujuk pada Undang-undang No. 27 tahun 2007, dijelaskan bahwa karena pulau-pulau kecil ini bidangnya sangat terbatas dan eksistensinya merupakan satu kesatuan ekosistem pesisir dan laut, maka karakteristik pulau-pulau kecil tidak boleh hanya dilihat sebagai bidang-bidang tanah saja. Oleh karena itu, di dalam Undangundang ini dikatakan bahwa, untuk pulau-pulau kecil maka hanya boleh dimanfaatkan pertama untuk kepentingan riset, pendidikan, dan wisata bahari itu dari sisi kelautan bahwa pulau itu betul-betul tidak boleh diperlakukan hanya sekadar bidang-bidang tanah. Tapi dia merupakan satu entitas biografis yang eksistensinya itu berkorelasi dan tidak bisa dipisahkan dengan perairan sekitarnya. Kedua, tujuan dari pengaturan perolehan hak ata tanah tersebut adalah agar pemanfaatan pulau-pulau kecil yg berpotensi dalam sektor pariwisata dan ekonomi tidak hanya dapat diasakan oleh kaum kapitalis semata, nanum tetap menjaga hak- hak masyarakat sekitar yg masih berada satu garis pantai dengan pulau kecil tersebut untuk sama-sama menfaatkannya baik dari segi sektor wisata maupun sektor ekonomi.

Dalam proses penataan pulau-pulau di Indonesia khususnya di Nusa Tenggara Barat, tentunya regulasi merupakan faktor utama yang harus diperhatikan oleh pemerintah. Artinya setiap aturan harus mencerminkan arah kebijakan dalam penetuan kepastian hukum terhadap tindakan hukum pemerintah dalam suatu pembangunan.

Menurut Soerjono Soekanto, penegakan hukum adalah kegiatan menyerasikan hubungan nilai-nilai yang terjabarkan didalam kaidahkaidah/pandangan nilai yang mantap dan mengejewantah dan sikap tindak sebagai rangkaian penjabaran nilai tahap akhir untuk menciptakan, memelihara dan mempertahankan kedamaian pergaulan hidup. Penegakan hukum secara konkret adalah berlakunya hukum positif dalam praktik sebagaimana seharusnya patut dipatuhi. Oleh karena itu, memberikan keadilan dalam suatu perkara berarti memutuskan hukum in concreto dalam mempertahankan dan menjamin di taatinya hukum materiil dengan menggunakan cara procedural yang ditetapkan oleh hukum formal. $^{7}$

Hakikatnya penegakan hukum mewujudkan nilai-nilai atau kaedahkaedah yang memuat keadilan dan kebenaran, penegakan hukum bukan hanya menjadi tugas dari para penegak hukum yang sudah di kenal secara

${ }^{7}$ Ibid hlm 33 
konvensional, tetapi menjadi tugas dari setiap orang. Meskipun demikian, dalam kaitannya dengan hukum publik pemerintahlah yang bertanggung jawab.

Dari hasil pengamatan penulis, ada beberapa faktor yang mempengaruhi hukum dalam penataan pulau-pulau kecil yang ada di Nusa Tenggara barat : 1) Faktor hukum : Sebagaimana yang telah penulis jelskan bahwa, ada beberapa regulasi yang digunakan pemerintah daerah Nusa Tenggara Barat dalam penataan pulau-pulau kecil khususnya pemberian hak atas tanah pada pulau tersebut diantaranya : UU No. 26 Tahun 2007, UU no 27 Tahun 2007, Perkaban No. 3 Tahun 1999 dan Perkaban No. 17 Tahun 2016 serta beberapa peratudan daerah. Dalam pelaksanaannya, peraturan perundang-undangan tersebut dijumpai adanya konflik norma sebagaimana yang telah penulis uraikan. Adanya konflik norma antara Perkaban No. 3 Tahun 1999 dengan Perkaban No. 17 Tahun 2016 khususnya berkenaan dengan kebijakan pemerintah dalam pemberian hak atas tanah pada pulau-pulau kecil, dapat memunculkan konflik dikemudian hari bagi pemerintah dengan investor maupun masyarakat karena adanya kehawatirnya monopoli penguasaan pulau-pulau kecil oleh kamu kapitalis. 2) Faktor penegakan hukum : Pentingnya penegakan dalam penataan pulau-pulau kecil khususnya izin pemanfaatan lahan menurut penulis sangatlah urgen. Masih banyak di temukan bangunan-bangunan yang tidak memiliki dokumen resmi dari pemerintah daerah sepertinya terjadi pada Gili Trawangan baru-baru ini. Selain itu pula, karna tidak ada penataan yang jelas terhadap berdirinya bangunan-bangunan seperti Café dan hotel menyebabkan pulau-pulau kecil yang menjadi objek wisata sering menimbulkan sengketa lahan antara investor dengan masyarakat. 3) Faktor sarana dan fasilitas pendukung : Untuk dapat memberlakukan peraturan perundang-undangan dalam penataan pulau-pulau kecil sebagaiaman yang telah penulis jelaskan, perlu adanya sarana baik dalam bentuk transportasi maupun sarana lainnya guna mendata, mengawasi serta mengelola pulau-pulau kecil yang ada di Nusa Tenggara Barat mengingat pulaupulau kecil tersebut memiliki potensi pariwisata yang sangat tinggi. 4) Faktor ekonomi : Dari hasil pengamatan penulis, selama ini pembangunan yang dilakukan pada pulau-pulau kecil di NTB lebih banyak (dominan) berorientasi untuk meraih keuntungan ekonomi jangka pendek dimana pemerintah seringkali mengeluarkan izin bagi investor untuk pembangunan gedung komersil tanpa memperhatikan kebijakan tata ruang yang ada sehingga berdampak kelestarian dan keindahan ekologi pulau tersebut. Selain itu pula, hal yang sangat disayangkan, banyak masyarakat yang memilik lahan di pulau-pulau kecil menjual tanah-tanah mereka dengan harga yang murah tanpa berfikir untuk mengembangkannya kedepan. Akibatnya, tidak jarang, masyarakat kita seperti yang ada di Gili Trawangan Maupun Gili air justru beralih profesi menjadi karyawan dengan upah yang rendah ditanah mereka sendiri.

\section{KESIMPULAN}

1. Kebijakan Penataan Pulau-Pulau Kecil Yang Mencerminkan Hukum Imperatif dapat dilihat dalam UndangUndang Nomor 27 tahun 2007 tentang dimana Pemanfaatan pulau-pulau kecil dan perairan di sekitarnya tidak hanya berorentasi pada komersialitas dari pemanfaatan pulau-pulau tersebut, namun tetap memperhatikan aspek pembangunan dan pelestariannya yang berkesinambungan. Untuk menwujudkan hal tersebut, ada dua aspek yang harus diperhatikan sebagaimana amanat UU NO 27 Tahun 2007 yakni adanya Perencanaan yang dilakukan melalui pendekatan Pengelolaan Wilayah Pulau-Pulau Kecil terpadu yang mengintegrasikan berbagai 
perencanaan yang disusun oleh sektor dan daerah sehingga terjadi keharmonisan dan saling penguatan pemanfaatannya, serta Pengelolaan yang merujuk pada Pemanfaatan dan pengusahaan pulau-pulau kecil melalui pemberian izin pemanfaatanya namun tetap memperhatikan kesejahteraan masyarakat sekitar pulau tersebut.

2. Mekanisme fungsi hukum dalam persyaratan menata hak pada pulaupulau kecil telah diuraikan dalam beberapa peraturan perundangundangan yang berlaku, salah satunya adalah Peraturan Menteri Agraria dan Tata Ruang/Kepala Badan Pertanahan Nasional No. 17 Tahun 2016 yang menjelaskan bahwa, pemberin hak atas tanah terhadap pulau-pulau kecil tidak lebih dari $70 \%$ luas pulau tersebut, dan 30\% digunakan untuk pengembangan ekosistem. Sementara, pada peraturan lainnya seperti PERKABAN No. 3 Tahun 1999 memberikan kesempatan untuk menguasai secara penuh suatu pulau jika pulau tersebut tidak lebih dari 2 Hektar. Hal ini tentu menyebabkan konflik norma yang tentu berdampak terhadap penataan pulau-pulau kecil tersebut.

3. Ada beberap faktor yang mempengaruhi hukum dalam penataan pulau-pulau kecil di Nusa Tenggara barat diantaranya masalah konflik norma pengaturan pulau-pulau kecil tersebut, faktor penegakan hukum, faktor sarana dan fasilitas pendukung serta faktor ekonomi.

\section{DAFTAR PUSTAKA}

\section{Buku dan Artikel}

Sudharto P. Hadi, Dimensi Sosial Dan Lingkungan Pengelolaan Wilayah Pesisir, Makalah Seminar Pengelolaan Wilayah Pesisir
Terpadu, UNDIP, Semarang, 7 Oktober 2004.

Satjipto Rahardjo, 2009. Hukum Progresif: Sebuah Sintesa Hukum Indonesia, Yogyakarta: Genta Publishing.

Adrianto L. Pembangunan dan Pengelolaan Pulau-pulau Kecil yang Berkelanjutan. Makalah disampaikan pada Pelatihan Perencanaan dan Pengelolaan Wilayah Pesisir secara Terpadu, Bogor, 23Agustus 2004.

\section{Jurnal Ilmiah}

Alam Ali, Syamsu. 2008. Analisis Pemanfaatan Ruang Dalam Pengelolaan Wilayah Pesisir dan Pulau-pulau Kecil.Selayar. Sulawesi Selatan.

Yanuarita, Dewi. 2003. Analisis

Pengembangan Wisata Bahari

Dipulau- pulau Bagian Selatan Kab.

Selayar. Program Pascasarjana.

Universitas Hasanuddin Makassar.

\section{Peraturan Perundang-undangan}

Indonesia, Undang-Undang Nomor. 26 Tahun 2007 tentang Penataan Ruang (Lembar Negara Nomor 68 tahun 2007, tambahan lembar Negara Nomor 4725)

Indoensia, Undang-Undang Nomor 27 Tahun 2007 tentang Pengelolaan Wilayah Pesisir dan Pulau-Pulau Kecil sebagaimana telah diubah dengan Undang-Undang Nomor 1 Tahun 2014 (Lembar Negara Republik Indonesia Nomor 2 Tahun 2014, Tambahan Lembar Negara Nomor 5490)

Indonesia, Keputusan Menteri Kelautan dan Perikanan Nomor : KEP 39/MEN 2004 Tentang Pedoman Umum Investasi di Pulau-Pulau Kecil.

Indonesia, Peraturan Menteri agraria dan Tata Ruang/Kepala Badan 
Durnal Iemu Hubum ] [Vol. 32 No.1, Maret 2017]

Pertanahan Nasional Republik Indonesia Nomor : 17 Tahun 2016 Tentang Penataan Pertanahan di Wilayah Pesisir dan Pulau-Pulau Kecil.

Indonesia, Peraturan Menteri Agraria Dan Tata Ruang/Kepala Badan Pertanahan Nasional Republik Indonesia Nomor : Nomor 3 Tahun $1999 \quad$ Tentang
Pelimpahan Kewenangan Pemberian Dan Pembatalan Keputusan Pemberian Hak Atas Tanah Negara.

\section{Internet}

Anonym. Perencanaan dan Pengembangan Wisata Alternatif di Gili Balu Sumbawa. www.google.com. Diakses pada tanggal 23 Januari 2017 